THE INTERNATIONAL

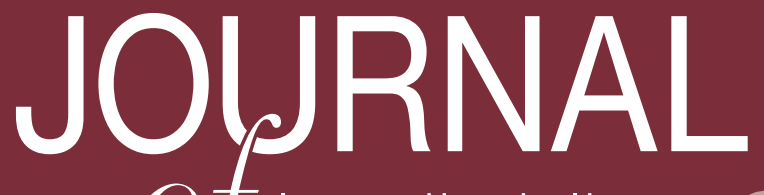

Of Interdisciplinary SOGAL

SGIENCES

Volume 5, Number 8

Social-cultural Engagements with Landscape: Why do we Visit Locations?

E. Anna Claydon 
THE INTERNATIONAL JOURNAL OF INTERDISCIPLINARY SOCIAL SCIENCES http://www.SocialSciences-Journal.com

First published in 2010 in Champaign, Illinois, USA by Common Ground Publishing LLC www.CommonGroundPublishing.com.

(C) 2010 (individual papers), the author(s)

(C) 2010 (selection and editorial matter) Common Ground

Authors are responsible for the accuracy of citations, quotations, diagrams, tables and maps.

All rights reserved. Apart from fair use for the purposes of study, research, criticism or review as permitted under the Copyright Act (Australia), no part of this work may be reproduced without written permission from the publisher. For permissions and other inquiries, please contact

<cg-support@ commongroundpublishing.com>.

ISSN: 1833-1882

Publisher Site: http://www.SocialSciences-Journal.com

THE INTERNATIONAL JOURNAL OF INTERDISCIPLINARY SOCIAL SCIENCES is peer-reviewed, supported by rigorous processes of criterion-referenced article ranking and qualitative commentary, ensuring that only intellectual work of the greatest substance and highest significance is published.

Typeset in Common Ground Markup Language using CGCreator multichannel typesetting system

http://www.commongroundpublishing.com/software/ 


\title{
Social-cultural Engagements with Landscape: Why do we Visit Locations?
}

\author{
E. Anna Claydon, University of Leicester, Leicestershire, UK
}

\begin{abstract}
Every day, most of us encounter an environment which holds significant to us beyond our immediate lives: passing a building we used to work in, seeing an image of somewhere we have been on holiday, walking through a city centre we have known all our lives and has changed as we have; but why do we humans feel the need to visit places which are more abstract for us and which become a vicarious experience of something others have lived or framed for us. Much has been discussed and critiqued in terms of the heritage industry we see across the world but in this paper I want to address something of the more specific function of visiting locations which we recognise from imaginary landscapes - not why visit the Tower of London (because we know it's history) but why visit a castle with no name seen distant on a hill? Not why visit the Universal Studios parks in the US or Japan (because it represents and imitation of Hollywood) but why visit some ruins in Ireland because they seem familiar? As such, this paper will drawing upon both the critical context of how we understand landscape as humans within that space but also original data gathered through questionnaires from people around the world in a small study of what we can call 'abstract tourism' and how this is a manifestation of our social-cultural engagements with space, place and identification.
\end{abstract}

Keywords: Landscape, Hourism, Heritage, Identity, History, Environment, Film Locations

\section{Introduction}

$\mathrm{E}$

VERY DAY, MOST of us encounter an environment which holds significance to us beyond our immediate lives: passing a building we used to work in, seeing an image of somewhere we have been on holiday, walking through a city centre we have known all our lives and has changed as we have; but why do we humans feel the need to visit places which are more abstract for us and which become a vicarious experience of something others have lived or framed for us. Much has been discussed and critiqued in terms of the heritage industry we see across the world but in this article I want to address something of the more specific function of visiting locations which we recognise from imaginary landscapes - not why visit the Tower of London (because we know it's history) but why visit a castle with no name seen distant on a hill? Not why visit the Universal Studios parks in the US or Japan (because it represents an imitation of Hollywood) but why visit some ruins in France because they seem familiar?

It is, however, difficult to get away from places and their names. Only very rarely do we stumble upon a location which is of interest but without cognitive meaning and even rarer is the accidental discovery of a place which does have meaning but which is utterly lacking in a label - for example in 2002 on holiday in Ireland my partner and I drove into Kells and strolled around some ruins, which were down a dirt track,only for me to realise that these were the ruins used by Stanley Kubrick in Barry Lyndon (1975) to represent the site of a regimental camp.

The International Journal of Interdisciplinary Social Sciences

Volume 5, Number 8, 2010, http://www.SocialSciences-Journal.com, ISSN 1833-1882

(c) Common Ground, E. Anna Claydon, All Rights Reserved, Permissions:

cg-support@commongroundpublishing.com 
Before I go further I want to establish that stylistically, you will note I use 'I' throughout this article. This journal is one of interdisciplinary social sciences and as someone who works at the intersection of humanities and social sciences the use of 'I' performs an important part in establishing my address to you the reader. I am not more than one person writing and will not use the royal 'we' but neither am I writing about something in which my position as ' $\mathrm{I}$ ' is irrelevant or insignificant to the analysis which follows, and as you will read in my discussion below of the work of Annette Kuhn my place as part of the text is relevant. Equally, it is crucial to acknowledge that my perspective on a large proportion of the texts analysed is influenced by knowledge but that this knowledge comes from interviewing the participants and the images themselves are largely alien to me as a spectator and, in objectifying them I am aware that readings occur which are both with and against the grain.

This article draws upon both the critical context of how we understand landscape as humans within that space but also original data gathered through questionnaires from people in an ongoing small study of what we can call 'abstract tourism' and how this is a manifestation of our social-cultural engagements with space, place and identification. The data cited in this article comes mainly from two families but with a particular focus on the story-arc of one family. It is worth focussing upon this particular narrative as it crosses the geographicalaesthetic history of three generations. Mostrespondents have largely responded as individuals yet in the case of the second family I discuss, create a picture of a family from a single perspective. However, I shall not draw upon the data gathered from the younger generation who responded much because different trends are evident there (in that the family holiday is less important) and more questions need to be asked from some of the respondents to gain as clear a picture as we do from these particular families. Nevertheless, it is the family history of re-visiting locations which is of primary interest to me and the case studies of the first family I am exploring in this article do indeed come from my own family as a pilot study.

\section{Methodology and Theory}

It is important to outline my methodology in both collecting the data and analysing the images. Family members (none of whom were under 18 or legally vulnerable) were initially asked to reflect upon four questions: Where did you go? When did you go? Why did you go in the first instance and why did you revisit the location? The answers to these questions then provided the search terms for the family photograph albums and the family was interviewed together (in order to encourage the communal memory to be reflected upon). Questions in interview expanded upon the basic four questions but permitted the development of ideas which emerged. This methodology proved effective with my own family and then was extended to families with similar age profiles (the chart which sets out one set of responses pre-photographic examination is below - chart 1). The specific analytical method is largely inspired by Annette Kuhn's influential Family Secrets: Acts of Memory and Imagination (1995) in which she analysed her own family album (but for a very different purpose) according to the following method:

1. Consider the human subject(s) of the photography. Start with a simple description, and then move into an account in which you take up the position of the subject. In this part of the exercise, it is helpful to use the third person ('she', rather than 'I', for instance). To bring out the feelings associated with the photograph, you may visualise yourself 
as the subject as she was at that moment, in the picture: this can be done in turn with all of the photograph's human subjects, if there is more than one, and even with inanimate objects in the picture.

2. Consider the picture's context of production. Where, when, how, by whom and why was the photograph taken?

3. Consider the context in which an image of this sort would have been made. What photographic technologies were used? What are the aesthetics of the image? Does it confirm with certain photographic conventions?

4. Consider the photograph's currency in its context of contexts of reception. Who or what was the photograph made for? Who has it now and where is it kept? Who saw it then, and who sees it now?

Kuhn, 1995: 7

I do not purport, in the analysis here, to examine all of the elements described above but the majority are considered whilst some, given the specificity of the limitations for this pilot study are in need to less emphasis. For Kuhn, the methodology leads to memory being triggered by examining photographic images of herself (and discovering something revealed within them that leads her to a better understanding of family dynamics); "The photograph is a prop, a prompt, a pre-text: it sets the scene for the recollection" (ibid, 12): but for me, the photograph itself also needs to be read in terms of a broader assessment of space and place which connects the human story to the aesthetic one more precisely. In Family Secrets, Kuhn sets out how her father was a professional photography and this impacts greatly upon her analysis of some imagery but in my analysis of these images I what to also consider how the aesthetic influences photographs taken without the professional photographer's eye, photographs which, to a significant extent, potentially reveal more about the intent behind the image than those which are conventionally and professionally framed to consciously present a somewhat clichéd family narrative (which is at the heart of the disjuncture in Kuhn's analysis).

The second key methodology which is used within is in analysing the semiotic qualities of the images. Annette Kuhn's list above covers many aspects which might be played under Barthes' hermeneutic code from $S / Z$ (1970) but the cultural, semic, action and symbolic codes are all in play in analysing the content of the images from the 1940 s to the $2000 \mathrm{~s}$. In summary, these codes are concerned with answering enigmas a text may set (hermeneutic), looking for the way in which cultural discourses influence our reading of a text (cultural), identifying the smallest units of meaning which denote something to the reader/viewer (semic), recognising the way in which motion is being communicated (action) and looking at how the meanings may function metaphorically to extend the reading of the text (symbolic).

A theory (or set of theories) which also figures in examining the reasoning behind the visiting of locations is that of a non-management oriented motivation theory: a theorising of 'why' we act in response to stimulate which goes beyond the prominent psychoanalytical readings of incentivisation in terms of 'drives' and can formulate motivation beyond the achievement of the ego-ideal. The motivation theories which dominate management theory and inflect most other motivation theories, Abraham Maslow's 1943 hierarchy of needs from physical needs to self-actuation andFrederick Hertzberg's 1959 division of needs into those which involved 'hygiene' (survival) and those which involved ambition (what he labelled 
the 'motivators'), frequently place the individual's needs above those of the community despite the fact that the understanding of these needs is a central tenet to management theory itself. There are some merits in Maslow and Hertzberg's theories, however, for examining the function of socially-shared events, such as the visiting of locations and particularly their re-visiting. These belong primarily not to the 'hygiene' functions of Hertzog's framework (in which physiological needs and safety are predominant, along with a sense of 'belonging' as a secondary issue) but in the 'motivator' functions which includes 'belonging' but prioritises the status of the individual's ego and then leads to self-actualisation - the position of fullest potential being reached or the most complete sense of an integrated self within society as a person of individual value. In visiting locations, it is possible to posit, the visitor is able to take some kind of ownership of the place through the memory of the place which provides both a sense of belonging and a practical boost the visitor's idea of their value within space and place and therefore encourages a created level of integration for individual and social identities.

The problem of much motivation theory being influenced by the two models discussed above is that most variant forms, albeit differently nuanced, can still be divided into extrinsic ('hygienic' - external) and intrinsic (pleasure or significance oriented- internal) forms. Nevertheless, it is from education's investigation of these motivations, and the question of what motivates a class of children and children as individuals that some of the more interesting contemporary framings of motivation theory appear, for in the work of Cassandra B. Whyte (2007, originally 1986) in which the ways in which internal motivators could be encouraged was investigated through 'situational motivators', the way in which the external, extrinsic can be used to elicit a response which is potentially counter to the model Maslow or Hertzberg would support. Specifically, that a dissatisfaction with external aspects could produce actions, which would result in a satisfaction with internal outcomes and vice versa. Situational motivation is a key factor in educational design from architecture to curriculum design and physical teaching but the very concept of the situational itself being intrinsically motivational is of interest when it comes to considering the 'pull' which some locations hold for some individuals. Are, for example, people who live in one part of a national more likely to feel a pull towards an environment, a situation, which is dialectically opposed to their dominant environment? Does a family return to holiday locations over generations because it is associated with 'home' and therefore safety? Do individuals visit new places in a conscious opposition of that which they have done before? All are possible and all contribute to the formulation of identities which are distinct from and also part of a social network.

Investigating what motivates individuals to action is central to the formation of identity if the proposition that identity is the effect of a series of causes is accepted. However, all identities, national, sexual, political are far more than the result of a set of events which can be quantified. Most aspects are learned but few are learned by a method of which the individual is fully conscious and, if an understanding of a behaviour becomes comprehendible through the recognition of it as a learned behaviours (as in cognitive theory), then the identity learned prior to long-term memory (and therefore remembrance as part of the cognitive act) becomes all the more difficult to secure as something other than pseudo-instinctual. It is only later in life, through the development of an understanding that identity is significantly manufactured that the reflective individual will revisit their identity as a product of ideologies and enter into their own behavioural therapy of sorts. 
In Landscape and Identity, Wendy Darby writes: "The construction of identity through recreational participation in valued and symbolic landscapes is a topic little explored in anthropology" (Darby, 2000: 2). Ten years since her analysis of fell walkers in the Lake District, this statement still largely holds with specific reference to how people physically interact with landscapes. "The representation of landscape", she continues, "is not innocent of a politics. It is deeply embedded in relations of power and knowledge" (ibid: 9). Thus, the represented landscape is an active space in which humans add further active meaning and is the potential site of a doubled political status: that of the place and that of different populations, permanent and temporary.

We should always think about landscapes is being something beyond the touristic but yet our participation in them is the very thing which makes them 'of the tour' - whether this be physical or in one's memory. Of course what we remember of the places we have visited and revisited is a core part of how landscapes contribute to the formulation of identity whether it is visiting somewhere you will remember little of or revisiting it because it becomes "where our family goes"... which moves us onto considering the first group of photographs, Skegness in 1947, 1954 and 1959.

\section{Skegness}

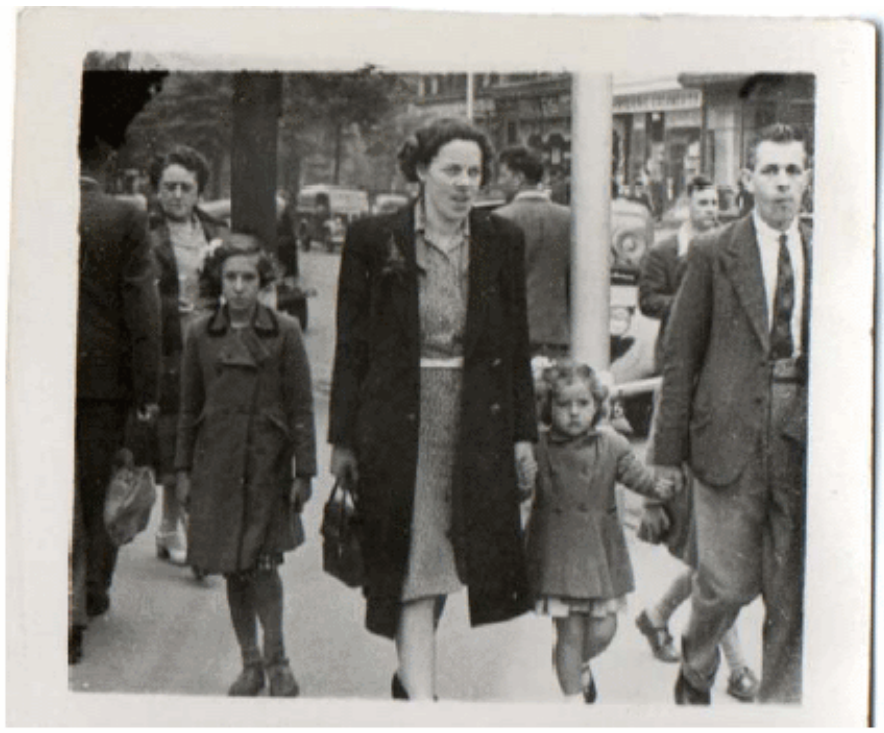

Fig. 1: Skegness, 1947

All three photographs come from the family album of Family 1: Male 1, 67 (working-class origin, military training); Female 1, 66 (upwardly mobile working-class origin, higher education); and Female 2, 35 (middle class, professional) and include repeated images of Female 1 as she aged from three (before she was attacked by polio only a few months later in 1947) to ten (her callipered leg notable exiting frame right) to fifteen (the length of her skirt and the shadows hiding the calliper). 
In the 1947 photograph (Figure 1) what can be seen is five figures facing the camera; on the right a man, tongue in cheek, looking directly at the camera but moving to the right of the photographer; next to him a small girl in a coat, holding his hand, also looking at the camera; holding her hand is a woman wearing an overcoat, her body shifting to the right. To the left of the woman is another girl of around ten standing straight onto the camera but her leg shows movement which indicates she too is caught in walking. Behind her, in the mid-distance, a middle-aged woman also stares at the photographer. What we see here is typical of the street photographer seen in many tourist locations in the mid-twentieth century, and it can be intimated that the three holding hands are attempting to move away from the photographer but the adults are moving counter to the little girl and the older child to the left. It is also clear that three of the figures are together but the girl on the left is also with the group - a childhood and neighbourhood friend brought along as company for the little girl according to Female 1.

The location of the image, other than it being a street photograph, is unclear but what is notable, as a holiday photograph, is that with the exception of the man, all are wearing overcoats. This places the image outside the main holiday season because if it had been a warmer time of year the coats would not be the woollen winter coats seen here. The fabric of the coats tells the viewer something of the financial situation of the individuals: that they have gone on holiday 'out of season', when it is cheaper. However, the specific fact that they have taken another child with them (which is not something we can conclude from the image itself), signifies that they can afford to do that and are in a position of security if not having extra money to spend. The socially specific circumstances of this family was that the man had not been to war but had been in a reserved occupation as a miner and was an ARP warden and had recently taken on a position of greater responsibility and higher pay but the ration books still made a different as the family had the woman's parents still living with the younger family.

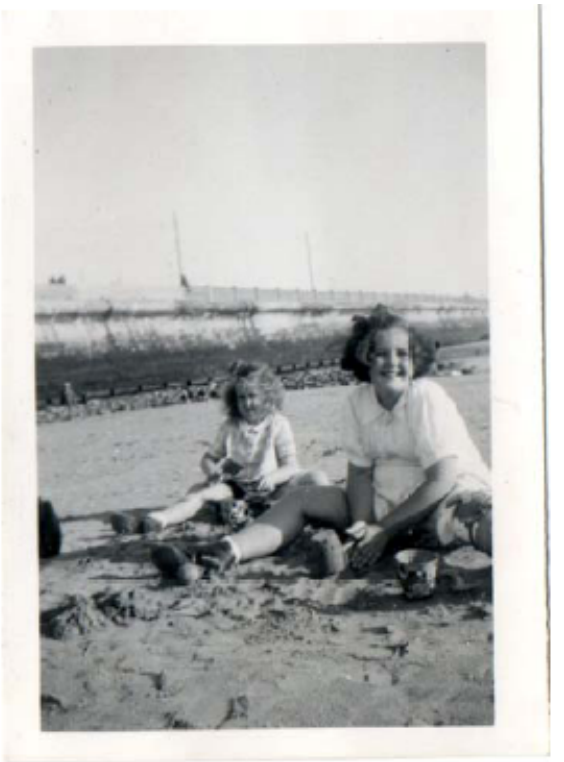

Fig. 2: Skegness, 1954 
By 1954, the photograph presents a different view (figure 2) - and in this image the location itself is revealed; a beach. That the beach is at Skegness is itself near impossible to determine from the photograph except by those who know Skegness well from this period. In this image, there are two girls, the elder being the earlier three year old at about ten and the younger girl is about six and, whilst the older child looks directly to the camera, the younger looks up more shyly. Both children, however, are dressed in summer dresses and this evidences that the family are financially able to holiday 'in season'. However, the time of the holiday also relates to the fact that both girls would now be at school and that the mother of the earlier image was a school caretaker at this time). It is also important to note that the two girls here are sisters - they have mutual playmates and whilst the younger child does not directly address the camera, the mirrored seating positions of the children show that they are playing 'together', a harmony not indicated by the earlier image as the older girl then is peripheral to the action.

I observed earlier that Female 1 aged ten wears a calliper on her left leg but that very little of it can be seen in the image. It is possible that this is to elide her disability from the family record but the family album does not bear this out - a family cannot edit out a disability and a later image of the girl at seventeen after an operation is as revelatory as the calliper off the end of the shot. The composition of this image as a whole is also more aesthetically pleasing that the 1947 street photographer's image showing both an aesthetic awareness and the time to create the image wanted. The photographer of this image was the mother of both girls and Female 1 noted that her mother would take the majority of the photographs on their childhood holidays. The very fact that the family had their own camera, progressing from an old box brownie to another camera in the 1950 s, is also a marker of their increased financial security.

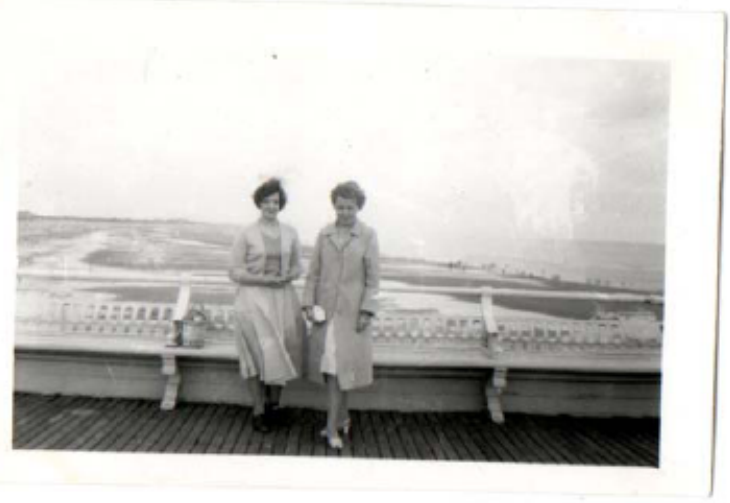

Fig. 3: Skegness, 1959

The last image from Skegness, in 1959 (Figure 3), is of two girls, clearly teenagers, nearly adults, stood by the rail at the seafront. Their hair is blown in the wind but whilst one girl (our growing Female 1) wears a cardigan the other is in a mackintosh. This photograph is not a family photograph. The girl in the mac' is not the sister older here but a friend, the same age as Female 1. The event was not a holiday but a day trip organised by the village youth club to Skegness. The photographer is not family but another friend, the sister of the girl in a coat. The fact that this is a non-family trip is important because it shows Female 1 choosing to revisit a place she already knows well with friends. Also important is that the girls come from a village. The relationship between where they have come from and where 
they have gone to is made all the more marked by it being midlands rural to seaside urban than if they had travelled from one town to another or one seaside to another. It makes difference and, two teenage girls away from parents, marks change on the horizon and the seaside as a place of possibilities - a cognitive understanding of the location is beginning to be played out.

Why did families from the British midlands, particularly from the 1930s to the 1960s visit a comparatively limited range of places: Skegness, Colwyn Bay, Rhyl and Blackpool? The answer is not just one of socio-economic reasons - that entire workplaces sometimes went to the same locations during the 'July fortnight' holidays (memorably explored in the 1933 and 1952 films ofHindle Wakes) - it is also a matter of building 'family traditions' in which a place accrues meaning not because of where specifically it is but because of the people with which it becomes associated. There is also another reason, one which is to some extent at odds with the two above - that wherever you go on holiday it is 'other' and therefore behaviours permissible on holiday are foregone at home("What happens in Vegas stays in Vegas"). But the photographs people take of their holiday destinations and places they've revisited tell the viewer of those images a great deal about the socio-cultural engagement with that space.

For whom are these images designed? Primarily, photographs are a souvenir - an aide de memoire if you like; but they can also be 'evidence' ("Been there, done that, got the t-shirt") or they can signal aspirations, interests or disinterests. The split between the 'evidentiary' photograph and the aide de memoire photograph is interesting and typified by the images in this presentation. The photographs taken for someone else ("We were here") are peopled, whilst the images taken for personal memory ("we were here") are more tellingly empty or (not seen here) emphasise the photographer through the absence of that figure from images of other recognisable faces.

There also tends to be a shift related to the photography of landscapes which is linked to when people own their first camera or go on their first holiday/day trip outside of the immediate family. In some families and in recent times, thisleads to the doubled

perspective of the locations visited and communicates significant 'tells' about the family dynamic just as photographs of a couple leak information like the now ubiquitous held at arm's length digital camera picture with which Facebook is littered. 
Holiday locations I have revisited (Middle-class male, 65)

\begin{tabular}{|c|c|c|c|}
\hline Location & When & Why in the first instance & Why revisited \\
\hline Cactan-on-sea & $\begin{array}{l}\text { As a child ia the late } 40 / \text { s } \\
\text { and eany so's }\end{array}$ & Family holidars & 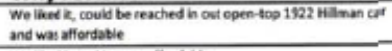 \\
\hline Broudstains, Kent & As acole in the mid $50 \mathrm{~s}$ & 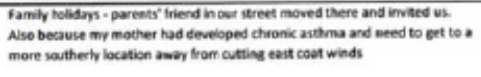 & We liend $k$ and its was aflerdatie \\
\hline Benhill Susser & As a vourg teenager & 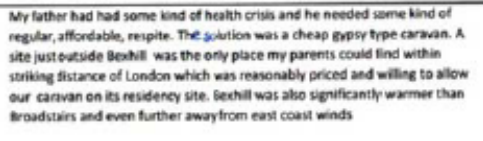 & Respite for my focther and mother : and affordable holdays \\
\hline Stenetherite, lakes & As a teenager & Develoged a passion for moumtainsering & Fed myparsien \\
\hline Ogeren, Snowiconia & As a teenager & $\begin{array}{l}\text { An aitenatve to the lakes which sould be hech-biand in a weetend during } \\
\text { school term time. Ale for holdary }\end{array}$ & Feeding my passion \\
\hline Giencole, Hietilundi & As a teenager & Uwedly i March/Apeil, for climbire on snow & Feeding my passion \\
\hline Aberpturts, West Wales & $\begin{array}{l}\text { As a pous poreas during } \\
\text { the } 70 \text { s and ars }\end{array}$ & 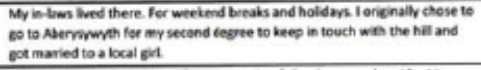 & Stresshu but a atherdable \\
\hline $\begin{array}{l}\text { Fin Mial, Fiver Orwel, East } \\
\text { coust }\end{array}$ & in the bate $80 \mathrm{~s}$ and $90 \mathrm{~s}$ & 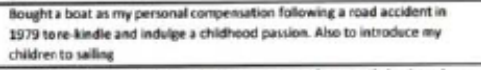 & Feeding my passion \\
\hline$\overline{\text { Giktany, Fance }}$ & $\begin{array}{l}\text { In the Late } 90 \% \text { s unt } \\
\text { about } 2006\end{array}$ & 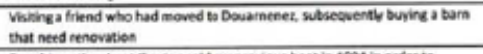 & $\begin{array}{l}\text { Transforming a clapidated bars, nd wendertul gatherings bir } \\
\text { ondsoer meals with odd and new fiend. }\end{array}$ \\
\hline $\begin{array}{l}\text { Fin Min Fiver Drwell East } \\
\text { ceast }\end{array}$ & Snce around 2003 & 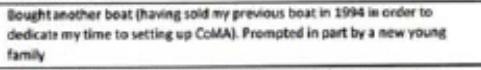 & 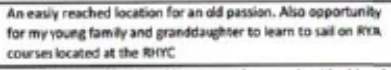 \\
\hline Knthirs, Greece & Frem 20 ? & 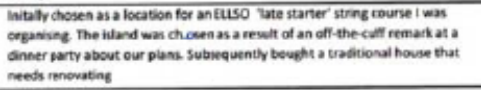 & 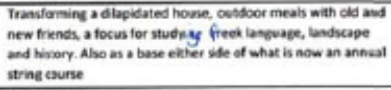 \\
\hline
\end{tabular}

Chart 1: A Lifetime of Holiday Locations

This initial pilot study was partly conducted through Facebook as the site has become a huge repository of holiday photographs and statements about the holidays people have been on. A Facebook 'app' also plots on a world map the places people have been and where they want to go or are going in the future. As such, sampling one's Facebook friends for some thoughts about landscapes and locations they have visited and revisited proves quite a rich and efficient way of gathering data and future work on this area can easily use network analysis to track the influence of other people's images/holidays on the decisions individuals or families make about places to visit. See, for example, the sheet of data (chart 1) which was a Facebook friend's Excel table of revisited holiday locations for his entire life. This is both quite detailed and useful but it is also telling just how many of the location decisions were not based upon something specific to the location other than the basic physical properties. But it does typify the fact that who one is revisiting a place with is just as, if not more, important than the place itself.

Many of the motivators identified in this individual's analysis of why he and his family went to specific places concern external factors and the fact that the situation of the location was deemed to be valuable. As a child, he notes for example that holidays were structured based upon his parents' variable health. However, as an adult, the situational motivators become explicitly connected to his internal growth, "feeding [his] passion" as he observes repeatedly. Thus, when he writes about holidays with his own children, there is a palpable sense of the holidays he took his children on in diametric opposition (if not consciously at that time) to those he himself had been taken on. Therefore, the situational motivation for the holidays he spent within his own children was a complex interaction between where he wanted to go for his internal needs, where he needed to go for his children's physical and educational needs and where he did not want to do as a result of his memory of his parents' needs. The memory shaped how he positioned himself and his own family within the imagined 
potential spaces for vacations. A familial social event had a direct effect upon later actions both within his family and, importantly for the later holidays he refers to, with his friends: the chosen social collective as opposed to the un-chosen grouping.

\section{Rochester}

Thirty-five years ago, writing in The Geographical Review, in an article no less accurate today, David Lowenthal wrote: "The collective past is no less precious that the personal; indeed the one is an extension of the other. The past is valued for the communal associations as well as its private ones. Particular features come to symbolise these shared recollections - for example, in Britain hedgerow and down land, Guy Fawkes effigies and Norman castles" (Lowenthal, 1975: 12). What Lowenthal is describing is a collective consciousness, if not memory, which ties the personal event to national identity as a cognitive process. An element of this process can be seen in the two photographs taken, from similar positions of Rochester Castle. I should note at this point that the images are part of a parallel group in which the photographer, Female 2, on revisiting the castle, took near identical images as her original visit.

Rochester Castle is precisely one of those "Norman castles" to which Lowenthal refers and had a specific role in helping to shape the history of England as one of the key erections in the wake of the Battle of Hastings... but as a building it is simply a ruin, devoid of narrative.

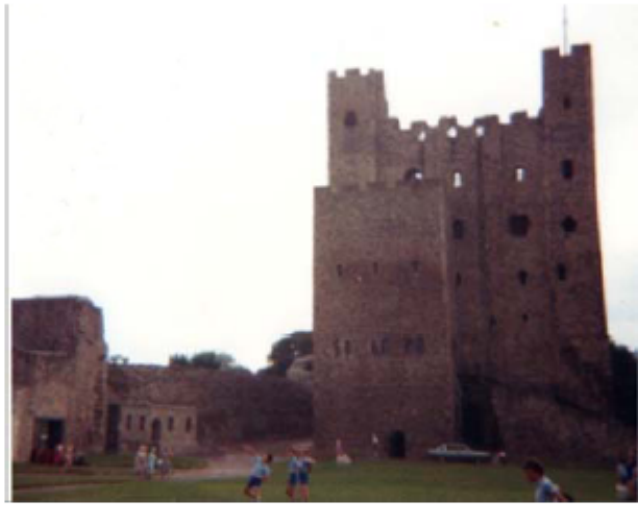

Fig. 4: Rochester Castle, 1987

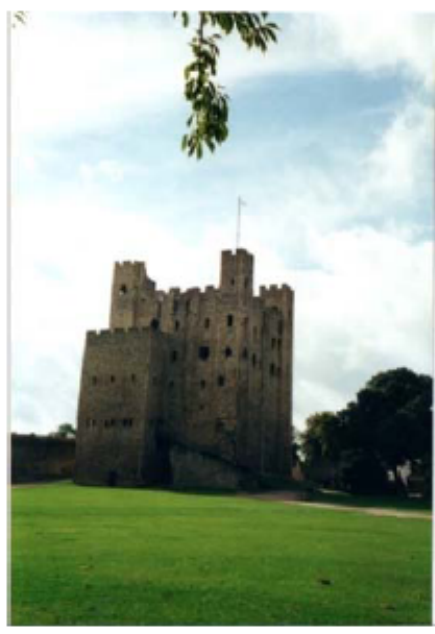

Fig. 5: Rochester Castle, 2001

When the photographer first visited the castle (figure 4), she was on a family holiday and the primary reason to visit Rochester was not the castle, or the cathedral, but the Charles Dickens museum. She was eleven or twelve and the holiday was one of series of 'educational' holidays she was taken on as a child or teenager. She had an avowed fondness for castles, a preference notable in her photo-albums by the preponderance of photographs, taken by here after she got her first camera at ten, of ruined castles. In 1987, the building's history was evident only through a guide book and the occasional information board so the pleasure in the building was purely as a building which evoked age and history rather than anything 
more specific - it was an arbitrary signifier of the Norman, no different to a helmet, but bigger. It had not yet gained the double significance Lowenthal ascribes to places as symbols - that "they serve to remind us of the past" (ibid) - which they did - and that "they require time and a past to become symbols" (ibid). To most children viewing a location this is true; although the status of a place as symbol may shift during that visit.

In 2001, Female 2 revisited the castle on a day-trip with her then new partner (figure 5). They did not go to the cathedral but they did go to the Dickens museum - but they spent more time at the castle than anywhere else. The photographer says that she wanted to show him "something I found interesting as a child". For her, the revisited location had attained its double significance but it was new for her partner. However, unlike the limited information of 1987, the castle's narrative was presented through an audio-guide and increased displays around the building. This meant that the knowledge/power relationship between the couple, whilst originally in her favour, was equalled quite rapidly.

The flow of information in revisiting places with others is clearly important when one individual chooses to share a location with another, even if the initial experience was communal, the sharing process makes it become private again - sharing the perspective as a secret might be shared. Lowenthal would link this to nostalgia for the past and the security of the past as something "we are already familiar with" (ibid: 5) but there is something much more personal happening in cases like this which is in addition to the recollection of the past - there is the concept of 'intimate space' in which the revisitor and the new visitor share a teacher/pupil dynamic eventually shifting to a position of equal knowledge and appreciation. This is not possible when a revisitor shows a location to multiple people because the communication shifts from a dialogue to a lecture and the private becomes the public irrespective of how well the people are known to one another. Neither is this possible if the 'teacher' knows more about a place but it is their first visit too because the information flow is one of data and not emotions. Thus, the dynamics at play in revisiting locations when only two people are concerned (irrespective of whether they are a couple or not) is primarily of emotional communication and intelligence rather than data communication and historical intelligence.

This emotional cognitive process is fundamental to why we revisit locations and I am sure most people can think of examples where they have made a decision based upon an emotional connection to a place. This emotional cognition can be conscious ("I want to share/show") but it can also be unconscious ("it's where the family always goes") and become habitual Indeed, the most dominant form or behavioural trend of this is habitual and conscious, such as revisiting a location on an important anniversary (or not revisiting it for similar reasons, evoking negative connotations).

Yet visiting places initially can have more complex origins. For a child there is little other than adult direction to work with but for adults reasons can be highly varied - from having read about it to having friends in the areas to simply putting a pin in a map. These processes and their development can clearly be seen in the data collected from the sixty-five year old male (chart 1) but they are also evident in the responses from Family 1 in how the destination decisions are reached. Much as in the relationship between the revisitor and visitor, the location decider holds much of the knowledge/power control and the child (Female 2) observed how this can create problems in a family holiday. Typically, her mother made the decisions about where the family went and, better educated and a former teacher, controlled the information completely. Throughout Female 2's childhood holidays, with the exception of when 
she was very young and the family would go to PorthMadoc in North Wales, her abiding memory of her father on holiday is cutting a somewhat lonely figure or driving. She had no idea whether he enjoyed the places they went to or not - and nowsuspects that the latter is true. The extent to which his motivators were being satisfied is debatable.

\section{Conclusions: Stonehenge}

In conclusion, I want to discuss Stonehenge. Female 1 visited Stonehenge in 1964 and took the photograph labelled "At the meeting of the four winds" (figure 6). The photograph is faded on the edges and it looks much older than it is because of the sepia quality the fading lends the image. Of ancient places and things, Lowenthal writes:

The aesthetic quality ascribed to primitive artifacts [sic] stems from both an association of ancient and natural and from a recognised gulf between our perspective and that of their creators. We attribute beauty to many early creations because we assume that those who made them found them so and that we ought to adapt the judgement we attribute to them.

This argument reflects two pervasive views. One is that primitive folk, unlike ourselves, created only artifacts [sic] they themselves considered beautiful. We romanticise the primitive past as an age when man lived in harmony and nature with himself when technology and art were one and the same.

Lowenthal, 1975: 19

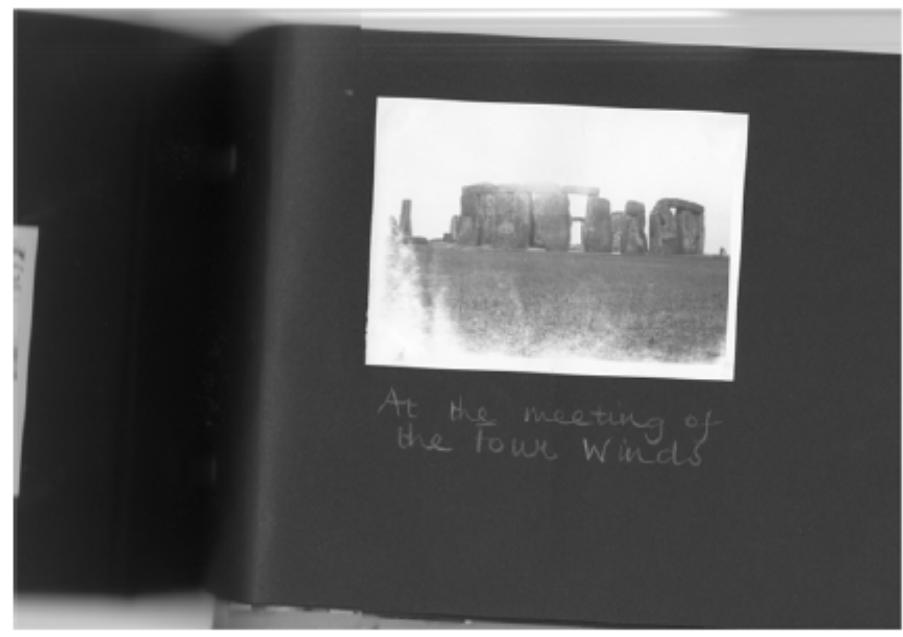

Fig. 6: Stonehenge, 1964 "At the meeting of the four winds"

At the time when the sixty-six year old woman first visited Stonehenge, she was an art student and the aesthetic argument, especially when we consider the trouble to which she went, as a disabled woman, to take the photograph by lying on her stomach on the ground.

This aesthetic quality argument brings us back to the concept of the visit to a location as being 'of the tour' - seeing a place. Years ago, Susan Sontag's seminal On Photography debated the 'problem' of the "Been there, done that" photograph as reducing the effect of 
the actual visit on the visitor - or the event on the participant. However, photography has become all the more dominant as evidence of participation and a contemporary counter-argument can now be positioned which is that digital photography - quick and auto-focussing - changes the nature of photographic participation in places when visited. When Female 1 photographed Stonehenge in 1964, she was trying to capture an artistic impression of the henge but today, the tourists who rush or amble past might video on tiny camcorders or take quick snaps almost as an afterthought - why they visit the place may be becoming less to say "because I wanted to prove my cultural awareness" and more "because I want to".

\section{References}

Darby, Wendy Joy (2000). Landscape and Identity: Geographies of Nation and Class in England. Oxford: Berg.

Hertzberg, Frederick; Mausner, Bernard; and Synderman, Barbara Bloch (1959). The Motivation to Work. New York: Wiley

Kuhn, Annette (1995). Family Secrets: Acts of Memory and Imagination. London: Verso.

Lowenthal, David (1975). 'Past Time, Present Place: Landscape and Memory'.The Geographical Review.Vol. 65. No. 1 (January 1975): 1-36.

Maslow, Abraham (1943). 'A Theory of Human Motivation', Psychological Review.Vol. 50. No. 1 (1943): 370-396.

Sontag, Susan (1986). On Photography. London: Faber \& Faber.

Whyte, Cassandra B. (2007). 'An Additional Look at Orientation Programs Nationally'. National Orientation Directors Association Journal.(Reprint of 1986 article for 30th Anniversary Edition).Vol. 15.No. 1 (2007).71-77.

\section{About the Author}

Dr. E. Anna Claydon

Dr. E. Anna Claydon is a lecturer in the Department of Media and Communication at the University of Leicester. She is currently working on the representation of the British rural landscape in the arts, masculinity in television crime dramas and disability on film and telelvision. 



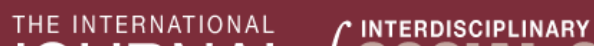 JOURNAL Of SOGHAL SGIENGES}

\section{EDITORS}

Mary Kalantzis, University of Illinois, Urbana-Champaign, USA.

Bill Cope, University of Illinois, Urbana-Champaign, USA.

\section{EDITORIAL ADVISORY BOARD}

Patrick Baert, Cambridge University, Cambridge, UK.

Norma Burgess, Syracuse University, Syracuse, USA.

Bill Cope, University of Illinois, Urbana-Champaign, USA.

Peter Harvey, University of Adelaide, Adelaide, Australia.

Vangelis Intzidis, University of the Aegean, Rhodes, Greece.

Paul James, RMIT University, Melbourne, Australia.

Mary Kalantzis, University of Illinois, Urbana-Champaign, USA.

Gerassimos Kouzelis, University of Athens, Athens, Greece.

Massimo Leone, University of Turin, Turin, Italy.

Alexandros-Andreas Kyrtsis, University of Athens, Athens, Greece.

José Luis Ortega Martín, Universidad de Granada, Granada, Spain.

Bertha Ochieng, University of Bradford, Bradford, UK.

Francisco Fernandez Palomares, Universidad de Granada, Granada, Spain.

Miguel A. Pereyra, Universidad de Granada, Granada, Spain.

Constantine D. Skordoulis, University of Athens, Athens, Greece.

Chad Turnbull, ESADE Business School, Barcelona, Spain.

Chryssi Vitsilakis-Soroniatis, University of the Aegean, Rhodes, Greece.

Please visit the Journal website at http://www.SocialSciences-Journal.com for further information about the Journal or to subscribe. 


\section{THE UNIVERSITY PRESS JOURNALS}

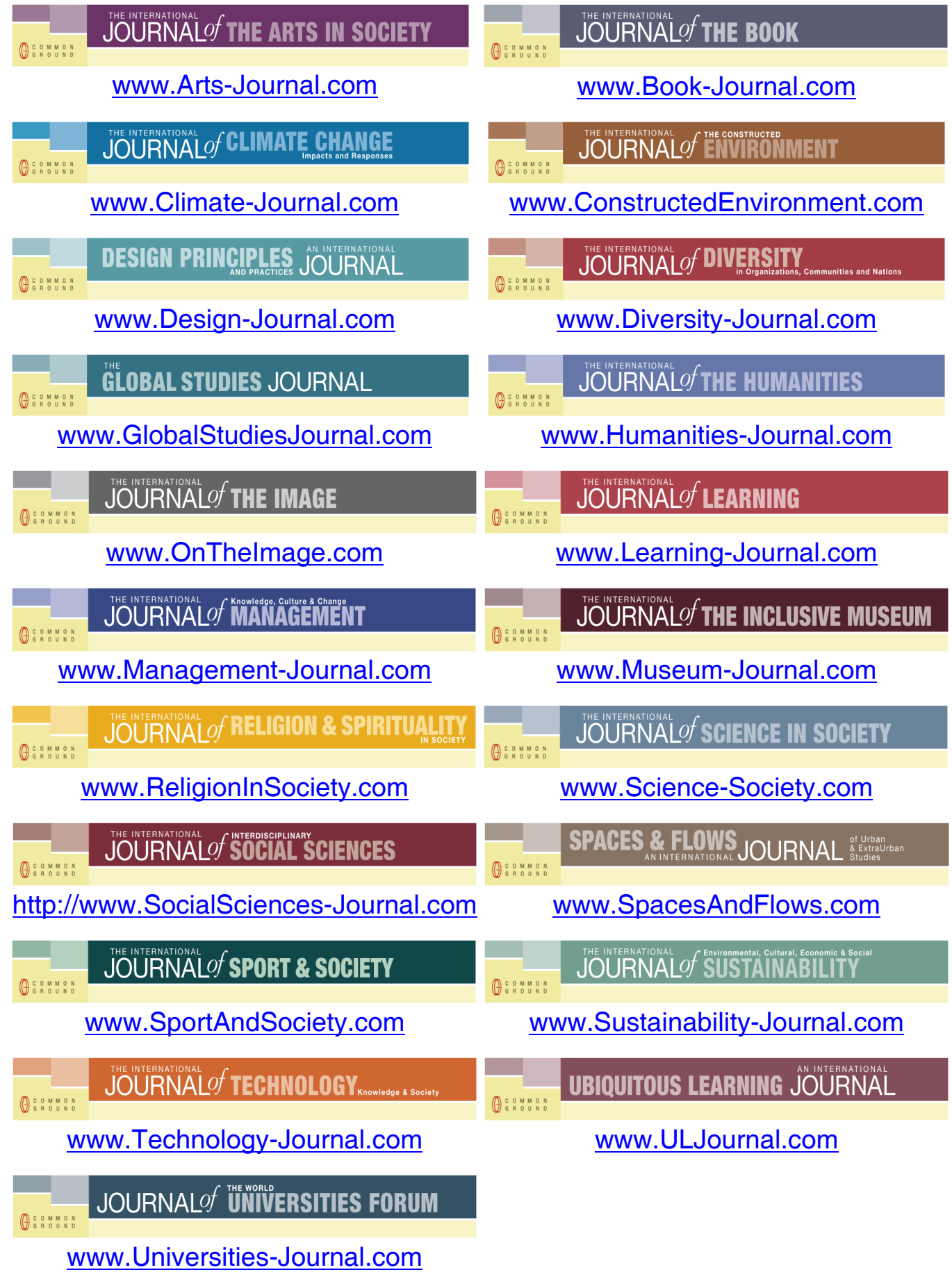

FOR SUBSCRIPTION INFORMATION, PLEASE CONTACT subscriptions@commongroundpublishing.com 